\title{
Comparative Study of Electrocardiographic Parameters among Tobacco Smokers and Tobacco Chewers
}

\author{
Renu Yadavi,*, Subodh Kumar Yadav²
}

\section{Renu Yadav ${ }^{1, *}$, Subodh Kumar Yadav ${ }^{2}$}

\section{${ }^{1}$ Assistant Professor, Department of Human Physiology, All Saints University School of Medical Sciences, Roseau, Common Wealth of Dominica, DOMINICA. \\ ${ }^{2}$ Assistant Professor, Department of Human Anatomy, All Saints University School of Medical Sciences, Roseau, Common Wealth of Dominica, DOMINICA.}

\section{Correspondence \\ Dr. Renu Yadav}

Department of Physiology, All Saints University, Roseau, Common Wealth of Dominica, DOMINICA.

Phone: +17672768269

Email: drresu@gmail.com

\section{History}

- Received: 02-09-2018

- Revised: 01-10-2018

- Accepted: 07-10-2018.

\section{DOI : 10.5530/ijcep.2018.5.3.5}

\section{Copyright}

(c) 2018 Phcog.Net. This is an openaccess article distributed under the terms of the Creative Commons Attribution 4.0 International license.

\begin{abstract}
Background and Aim: Nicotine and other components of cigarette can produce profound changes in the heart, which can be assessed by doing electrocardiogram (ECG). The present study compares the vitals and ECG parameters among tobacco non-smokers (controls), tobacco smokers and tobacco chewers. Methods: One hundred and fifty healthy male volunteers, age group of 18-25 years from outpatient department, were included for the study. The subjects were divided into group 1 (control, $n=50$ ), group 2 (tobacco smokers, $\mathrm{n}=50$ ) and group 3 (tobacco chewers, $\mathrm{n}=50$ ). Subjects were asked to abstain tobacco and beverages consumption 2 hours prior to recording ECG. The subject's vital: blood pressure and ECG parameters: heart rate, OT interval, OTc (corrected QT interval) were recorded in physiology lab of Nobel Medical College and Teaching Hospital, Nepal. Results: The data analysis was done by independent student " $t$ " test. The data analysis showed significant increase in blood pressure on comparison of group 1 with group $2(p=0.001)$ and group 3 $(p=0.001)$ respectively. The data analysis of ECG parameters also showed decrease in OT and QTc (corrected QT) comparing group 1 with group $2(p=0.001)$ and group $3(p=0.001)$ separately which was highly significant. There was significantly increase in heart rate on comparison of group 1 separately with group 2 and group 3. Conclusion: The study concluded that the consumption of either smoked or chewed form of tobacco adversely affects cardiovascular system.
\end{abstract}

Key words: Electrocardiogram, Abstain, Blood pressure, QTc.

\section{INTRODUCTION}

Tobacco smoking is the single most cause of the preventable death globally. Tobacco is consumed in many forms and one such form is cigarette smoking. ${ }^{[1]}$ By the early $19^{\text {th }}$ century tobacco was rolled in paper, smoked as cigarettes and rapidly marketed all over the world. Beyond nicotine, the main constituent of tobacco responsible for its additive character, unburned tobacco contains carcinogens and other toxins capable of causing gum disease and oral cancers. ${ }^{[2]}$ Cigarette smoking increases the relative risk of coronary artery disease by 2.8 -fold and 3.1-fold in young (35-64 years) men and women, respectively. ${ }^{[3]}$ Smoking is associated with increased ventricular premature beats and it is a strong risk factor for sudden cardiac death. ${ }^{[4]}$ Effect of smokeless tobacco consumption on cardiovascular events has been studied in detail in western population. Results from these studies paint a mixed picture with some showing increased incidence of these adverse events. ${ }^{[5,6]}$

The cardiac effects of nicotine are attributed to the release of catecholamine, which are released due to the binding of nicotine to the nicotinic cholinergic gate on the cation channels in receptors (nAchRs) throughout the body. ${ }^{[7]} \mathrm{A}$ longer retention of nicotine occurs in the blood and in other specific tissues such as the oesophagus, fundus, antrum, spleen, caecum, pancreas, testes, heart and the muscle via a constant exposure. ${ }^{[8]}$ Nicotine is a potent inhibitor of the cardiac A type potassium channels, which contributes to the changes in the electrophysiology and it also induces arrhythmias. ${ }^{[9}$

Nicotine and other components of cigarette can produce profound changes in the heart, which can be assessed by doing electrocardiogram (ECG). A number of studies have strongly correlated the role of smoking in causative factor for CAD but a very little work has been done on tobacco chewers.

\section{MATERIALS AND METHODS}

The present study was conducted in Nobel Medical College and Teaching Hospital in department of physiology lab, Nepal from April 2017 to September 2017. The subjects were selected from the out-patient department by questionair who were light to heavy smokers and physically healthy attendants. The age of the selected subject was $20.3 \pm 1.48$ (mean \pm SD) years. The subjects were included in the study after written consent was taken. Selected subjects were divided into three groups.

Group 1: Normal healthy Population (Neither smoked nor chewed, $\mathrm{n}=50$ ) 
Group 2: Exclusive light to heavy smokers (Only smoked the filtered cigarette, $\mathrm{n}=50$ )

Group 3: Exclusive Chewers (Only chewed the bhola gutkha, $n=50$ ).

Light Smokers -A person who smokes 10 or less than 10 tobacco products per day. Heavy Smokers - A person who smokes more than 10 but less than 20 tobacco products per day.

This is a case control study. The cases are exclusively smokers, smokeless tobacco users and controls (did not consume tobacco in any form). A working proforma (case sheet) was filled for every subject. It included demographic data [particulars of subject like name, age, sex, address, contact number], past history and family history of chronic illness. Further addiction history was taken which included type, amount and duration of consumption of smokeless tobacco and cigarette.

The subjects having history of cardiovascular illness, renal disease, diabetes, obstructive or restrictive lung disease and drug consumption for prolong duration were excluded from the study.

Measurement of blood pressure was carried out along with the height, weight and BMI after the subjects were thoroughly acquainted with working of the corresponding instrument.

After 5 mins of rest, the resting heart rate, QT, QTc, were measured in both nonsmokers and smokers group, with the help of Cardiart 108T-mk-VI; Electrocardiograph (ECG) machine manufactured by BPL India Ltd., which is a single channel, 12 lead selection electrocardiograph designed to record electrocardiograms. Three Silver-chloride $(\mathrm{Ag}-\mathrm{Cl})$ electrodes were used to record ECG signal. The electrodes were connected with ECG machine and were affixed on right arm (RA), left arm (LA) and left leg (LL) of the subject. Ground electrode was placed on right leg (RL) of the subject. Hardware setting of ECG were: Gain: 10, Mode: Normal, Low pass filter: $35 \mathrm{~Hz}$, High pass filter: $0.5 \mathrm{~Hz}$. Recording was done for limb lead I, II and III. Lead II was used for analysis of QT, QTc and heart rate

\section{Statistical Analysis of data}

Statistical Analysis was done using SPSS (Statistical Package for Social Sciences) version 18. A $P$-value of less than $0.005(P<0.005)$ was considered to be statistically significant.

\section{RESULTS}

A total of 150 male subjects from the outpatient department were included in the study.

Statistical analysis showed increase in blood pressure and heart rate which is highly significant $(p<0.005)$ comparing group 1 with group 2 and group 3 separately.

Table 1: Anthropometric variables of non-smokers, smokers and gutkha chewers.

$\begin{array}{cccc}\text { Parameters } & \begin{array}{c}\text { non-smokers } \\ (\text { mean } \pm \text { SD })\end{array} & \begin{array}{c}\text { Smokers } \\ (\text { mean } \pm \text { SD })\end{array} & \begin{array}{c}\text { gutkha chewers } \\ \text { (mean } \pm \text { SD) }\end{array} \\ \begin{array}{c}\text { Age } \\ \text { (years })\end{array} & 20.3 \pm 1.5 & 20.06 \pm 1.5 & 19.74 \pm 1.35 \\ \text { Height }(\mathrm{cm}) & 162.6 \pm 7.12 & 162.08 \pm 5.5 & 167.74 \pm 6.73 \\ \text { Weight }(\mathrm{kg}) & 59.72 \pm 3.64 & 60.08 \pm 3.8 & 65.96 \pm 6.04 \\ \begin{array}{c}\mathrm{BMI} \\ \left(\mathrm{kg} / \mathrm{cm}^{2}\right)\end{array} & 22.6 \pm 1.06 & 22.87 \pm 1.09 & 23.88 \pm 3.53 \\ & & & \end{array}$

QT interval and QTc between group 1, group 2 and group 3 were also significantly increased in tobacco smokers (group 2) and tobacco chewers (group 3).

\section{DISCUSSION}

Smoking during life can have a profound impact on the overall health of the smoker and cardiovascular health in particular. Therefore the present study was planned to examine the correlation between smoking and changes occurring in blood pressure and ECG. The present study was conducted in male subjects which showed the comparison between tobacco smokers (20.06 \pm 1.5 years) and tobacco chewers $(19.74 \pm 1.35$ years) with controls ( $20.3 \pm 1.5$ years).

Our study showed the significantly increase in heart rate in smokers and chewers compared to controls. This study is consistent with the result of Amit Srivastava et al where there was significant decrease in R-R interval in smokers compared to non-smokers. Heart rates were $74 \pm 2$ and $83 \pm$ 3 among nonsmokers and smokers respectively. ${ }^{[10]}$ The study by Salman S Siddhiqui et al showed the similar result of increase in heart rate in smokers $(88.56 \pm 5.06)$ as well as chewers $(85.29 \pm 4.7)$ compared to controls $(72.2 \pm 8.4) .^{[11]}$ Vankatesh $G$ et al. reported the heart rates $76.0 \pm 6.9$ and $80.8 \pm 10.2$ among controls and smokers respectively which also concluded the increase in heart rate in smokers. ${ }^{[12]}$

The QT and the QTc interval in the present study are significantly decreased as compared to control. The QT in smokers $(0.3 \pm 0.037)$ and chewers $(0.34 \pm 0.028)$ compared to control $(0.37 \pm 0.035)$ was significantly decreased. Similarly, the QTc in smokers $(0.4 \pm 0.032)$ and chewers $(0.35 \pm 0.041)$ comparing with control $(0.37 \pm 0.03)$ also significantly decreased in present study. The study conducted by Salman S Siddiqui showed the decrease in QT interval which was not significant but the QTc was not calculated. ${ }^{[11]}$ The study of Amit Srivastava et al showed that the QTc interval of nonsmokers is $0.32 \pm 0.013$ and smokers is $0.36 \pm 0.042$ which is not clinically significancant. ${ }^{[10]}$ The study is not consistent with present study which might be because of small sample size. The systolic blood pressure was 140 and diastolic blood pressure was 90 in tobacco smokers compared to controls which were 120 and 70 respectively and were statistically significant $(p<0.0001)$ in a study by Vandana V. Chiddarwar et al. ${ }^{[13]}$ Our study also showed the increased systolic (smokers $=120.04 \pm 5.78$, chewers $=118.92 \pm 4.21$ ) and diastolic blood pressure $($ smokers $=98.4 \pm 6.26$, chewers $=94.88 \pm 8.77$ ) compared to control (systolic $=112.2 \pm 6.73$, diastolic $=89.7 \pm 6.5$ ).

\section{Limitations of the study}

The sample size was modest in the study. Hence the correlation of smoking status with cardiovascular parameters has not been done.

Table 2: Vitals and ECG parameters of non-smokers, smokers and gutkha chewers.

$\begin{array}{cccc}\text { Parameters } & \begin{array}{c}\text { Group 1 } \\ \text { (mean } \pm \text { SD) }\end{array} & \begin{array}{c}\text { Group 2 } \\ \text { (mean } \pm \text { SD) }\end{array} & \begin{array}{c}\text { Group 3 } \\ \text { (mean } \pm \text { SD) }\end{array} \\ \begin{array}{c}\text { Systolic BP } \\ \text { (mmHg) }\end{array} & 112.2 \pm 6.73 & 120.04 \pm 5.78 & 118.92 \pm 4.21 \\ \begin{array}{c}\text { Diastolic BP } \\ (\mathrm{mmHg})\end{array} & 89.7 \pm 6.5 & 98.4 \pm 6.26 & 94.88 \pm 8.77 \\ \begin{array}{c}\text { Heart Rate } \\ \text { (beats/min) }\end{array} & 70.4 \pm 5.9 & 83.06 \pm 8.2 & 75.59 \pm 6.51 \\ \begin{array}{c}\text { QT interval } \\ (\mathrm{sec})\end{array} & 0.37 \pm 0.035 & 0.3 \pm 0.037 & 0.34 \pm 0.028 \\ \text { QTc }(\mathrm{sec}) & 0.4 \pm 0.032 & 0.35 \pm 0.041 & 0.37 \pm 0.03\end{array}$


Table 3: Statistical analysis of Vitals and ECG parameters for levels of significance among group 1, group 2 and group 3.

\begin{tabular}{|c|c|c|c|c|c|c|c|}
\hline \multicolumn{8}{|c|}{ Bonferroni } \\
\hline \multirow[t]{2}{*}{ Variables } & \multirow[t]{2}{*}{ Groups } & \multirow[t]{2}{*}{ Groups } & \multirow[t]{2}{*}{ Mean Difference } & \multirow[t]{2}{*}{ Std. Error } & \multirow[t]{2}{*}{ Significance } & \multicolumn{2}{|c|}{ 95\% Confidence Interval } \\
\hline & & & & & & Lower Bound & Upper Bound \\
\hline \multirow[t]{6}{*}{ Systolic BP } & \multirow[t]{2}{*}{1} & 2 & $-7.84000^{*}$ & 1.14661 & $0.0001^{*}$ & -10.6167 & -5.0633 \\
\hline & & 3 & $-6.72000^{*}$ & 1.14661 & $0.0001^{*}$ & -9.4967 & -3.9433 \\
\hline & \multirow[t]{2}{*}{2} & 1 & $7.84000^{*}$ & 1.14661 & $0.0001^{*}$ & 5.0633 & 10.6167 \\
\hline & & 3 & 1.12 & 1.14661 & 0.991 & -1.6567 & 3.8967 \\
\hline & \multirow[t]{2}{*}{3} & 1 & $6.72000^{*}$ & 1.14661 & $0.0001^{*}$ & 3.9433 & 9.4967 \\
\hline & & 2 & -1.12 & 1.14661 & 0.991 & -3.8967 & 1.6567 \\
\hline \multirow[t]{6}{*}{ Diastolic BP } & \multirow[t]{2}{*}{1} & 2 & $-7.10000^{*}$ & 2.03626 & $0.002^{*}$ & -12.0312 & -2.1688 \\
\hline & & 3 & $-5.18000^{*}$ & 2.03626 & $0.036^{*}$ & -10.1112 & -0.2488 \\
\hline & \multirow[t]{2}{*}{2} & 1 & $7.10000^{*}$ & 2.03626 & $0.002^{*}$ & 2.1688 & 12.0312 \\
\hline & & 3 & 1.92 & 2.03626 & 1 & -3.0112 & 6.8512 \\
\hline & \multirow[t]{2}{*}{3} & 1 & $5.18000^{*}$ & 2.03626 & $0.036^{*}$ & 0.2488 & 10.1112 \\
\hline & & 2 & -1.92 & 2.03626 & 1 & -6.8512 & 3.0112 \\
\hline \multirow[t]{6}{*}{ Heart Rate } & \multirow[t]{2}{*}{1} & 2 & -12.5796 & 1.40432 & $0.0001^{*}$ & -15.9804 & -9.1788 \\
\hline & & 3 & $-5.10540^{*}$ & 1.40432 & $0.001^{*}$ & -8.5062 & -1.7046 \\
\hline & \multirow[t]{2}{*}{2} & 1 & $12.57960^{*}$ & 1.40432 & $0.0001^{*}$ & 9.1788 & 15.9804 \\
\hline & & 3 & $7.47420^{*}$ & 1.40432 & $0.0001^{*}$ & 4.0734 & 10.875 \\
\hline & \multirow[t]{2}{*}{3} & 1 & $5.10540^{*}$ & 1.40432 & $0.001^{*}$ & 1.7046 & 8.5062 \\
\hline & & 2 & $-7.47420^{*}$ & 1.40432 & $0.0001^{*}$ & -10.875 & -4.0734 \\
\hline \multirow[t]{6}{*}{ QT interval } & \multirow[t]{2}{*}{1} & 2 & $.06960^{*}$ & 0.00688 & $0.0001^{*}$ & 0.0529 & 0.0863 \\
\hline & & 3 & $.03440^{*}$ & 0.00688 & $0.0001^{*}$ & 0.0177 & 0.0511 \\
\hline & \multirow[t]{2}{*}{2} & 1 & $-.06960^{*}$ & 0.00688 & $0.0001^{*}$ & -0.0863 & -0.0529 \\
\hline & & 3 & $-.03520^{*}$ & 0.00688 & $0.0001^{*}$ & -0.0519 & -0.0185 \\
\hline & \multirow[t]{2}{*}{3} & 1 & $-.03440^{*}$ & 0.00688 & $0.0001^{*}$ & -0.0511 & -0.0177 \\
\hline & & 2 & $.03520^{*}$ & 0.00688 & $0.0001^{*}$ & 0.0185 & 0.0519 \\
\hline \multirow[t]{6}{*}{ QTc } & \multirow[t]{2}{*}{1} & 2 & $.05260^{*}$ & 0.00722 & $0.0001^{*}$ & 0.0351 & 0.0701 \\
\hline & & 3 & $.02940^{*}$ & 0.00722 & $0.0001^{*}$ & 0.0119 & 0.0469 \\
\hline & \multirow[t]{2}{*}{2} & 1 & $-.05260^{*}$ & 0.00722 & $0.001^{*}$ & -0.0701 & -0.0351 \\
\hline & & 3 & $-.02320^{*}$ & 0.00722 & $0.005^{*}$ & -0.0407 & -0.0057 \\
\hline & \multirow[t]{2}{*}{3} & 1 & $-.02940^{*}$ & 0.00722 & $0.0001^{*}$ & -0.0469 & -0.0119 \\
\hline & & 2 & $.02320^{*}$ & 0.00722 & $0.005^{*}$ & 0.0057 & 0.0407 \\
\hline
\end{tabular}

$\mathrm{P}<0.005$ is considered highly significant, ${ }^{*}=$ highly significant

\section{CONCLUSION}

Smoking during life can have a profound unwanted impact on the overall health of the smoker and cardiovascular health in particular. Thus the study strongly discourage the smoking of young individuals for the healthy long life.

\section{ACKNOWLEDGEMENT}

I would like to show my gratitude towards my previous institute, Nobel Medical College and Teaching Hospital, Nepal, for the full support throughout my research work. I wish to thank my Head of Department, Dr Soumitra Mukhopadhyay from the same institute for his aspiring guidance.

\section{CONFLICT OF INTEREST}

The authors declare no conflicts of interest.

\section{ABBREVIATIONS}

CAD: Coronary Artery Disease.

\section{SUMMARY}

On analysis ECG for 150 healthy male volunteers who were tobacco chewers and smokers, it was concluded that the consumption of either form of tobacco adversely affects the cardiovascular system 


\section{REFERENCES}

1. Ockene IS, Miller NH. Cigarette Smoking, CVS disease and Stroke. A Statement for healthcare professionals from the American Heart Association. Circulation. 1997;96(9):3243-7.

2. Ambrose JA, Barua RS. The pathophysiology of cigarette smoking and cardiovascular disease: an update. J Am Coll Cardiol. 2004;43(10):1731-7.

3. Prasad DS, Kabir Z, Dash AK. Smoking and cardiovascular health: a review of the epidemiology, pathogenesis, prevention and control of tobacco. Indian J Med Sci. 2009;63:520-33.

4. Ezzati M, Henley SJ, Thun MJ, lopez AD. Role of smoking in global and regional cardiovascular Mortality. Circulation. 2005;112(4):489-97.

5. Bolinder G, Alfredsson L, Faire DU. Smokeless tobacco use and increased cardiovascular mortality among Swedish construction workers. Am J Public Health. 1994;84(3):399-404. PMC1614817

6. Huhtasaari F, Lundberg V, Eliasson M, Janlert U, Asplund K. Smokeless tobacco as a possible risk factor for myocardial infarction: a population-based study in middle-aged men. J Am Coll Cardiol. 1999;34(6):1784-90.
7. Stewart PM, Cetterall JR. Chronic nicotine ingestion and atrial fibrillation. $\mathrm{Br}$ Heart J. 1985;54(2): 222-3.

8. Chowdhury P, Doi R, Chang LW, Rayford PL. Tissue distribution of [3H]-nicotine in rats. Biomed Environ Sci. 1993;6(1):59-64.

9. Huizhenwang. Hang SMD, Baofeng Y. Nicotine is a potent Blocker of the cardiac A- type K+ Channels. Circulation. 2000;102(10):1165-71.

10. Srivastava $A$, et al. A comparative study of electrocardiographic changes between non-Smokers and smokers. IJCSET. 2012;2(5):1231-3

11. Siddhiqui S. A Comparision of 12 lead ecg status of tobacco smokers, tobacco chewers and nontobacco users. National Journal of Medical Research. 2013;3(3):203-5

12. Venkatesh G, Swamy RM. A Study of Electrocardiographic changes in smokers compared to normal human beings. Biomedcal Research. 2010;21(4):389-92.

13. Vandana V, Chiddarwar, et al. Short term impact of smoking on cardio-vascular functioning in adults from industrial town in Western Maharashtra, India. Int J Pharm Biomed Sci. 2012;3(4):220-3.

Cite this article: Yadav R, Yadav SK. Comparative Study of Electrocardiographic Parameters among Tobacco Smokers and Tobacco Chewers. ijcep. 2018;5(3):127-30. 